\title{
İlkokul 4. Sınıf Öğrencilerinin Sorumluluk Düzeylerinin Çeşitli Değişkenler Açısından İncelenmesi ${ }^{1}$
}

\section{Investigation of Primary School 4th Grade Students' Levels of Responsibility in Terms of Various Variables}

\author{
Halil İbrahim SAĞLAM², Büşra KAPLANCI ${ }^{3}$
}

\section{Öz}

Bu araştırma ilkokul 4. sınıf öğrencilerinin sorumluluk düzeylerini belirlemek amacıyla yapılmıştır. Araştırmada tarama yönteminden yararlanılmıştır. Bu amaçla, tek boyutlu 24 maddelik 3'lü likert tipi Sorumluluk Ölçeği kullanılmıştır. Araştırmanın çalışma grubunu, 2017-2018 eğitim öğretim yılında Sakarya ilinde öğrenim gören 417'si (\%49) kız, 427'si (\%51) erkek olmak üzere toplam 844 ilkokul 4. sınıf öğrencisi oluşturmaktadır. Araştırmada ilkokul öğrencilerinin sorumluluk düzeylerinin üst seviyeye yakın olduğu; öğrencilerin cinsiyetlerine göre sorumluluk düzeylerinin kız öğrenciler ve öğretmeni kadın olan öğrenciler lehine anlamlı bir şekilde farklılaştığı; öğrencilerin öğretmenlerinin medeni durumlarına göre sorumluluk düzeylerinin öğretmeni bekâr olan öğrenciler lehine anlamlı bir şekilde farklılaştığı; öğrencilerin devam ettikleri okul türüne ve öğrencilerin aile türüne göre sorumluluk düzeylerinin anlamlı bir şekilde farklılaşmadığı sonucuna ulaşılmıştır. Elde edilen bulgular literatür ışığında tartışımış ve yeni araştırmalar için önerilere yer verilmiştir.

Anahtar Kelimeler: Sorumluluk, değer, ilkokul, sosyal bilgiler

\section{Abstract}

This study was conducted to determine the level of responsibility of the 4th grade students in elementary school. The research was conducted with screening method. For this purpose, one-dimensional 24-item 3-point Likert-type Responsibility Scale was used. The study group consisted of 417 (49\%) female and 427 (51\%) male and 844 primary school 4th grade students who were studying in Sakarya in the 2017-2018 academic year. In the research, it was found that the level of responsibility of primary school students was close to the upper level; that the level of responsibility of students according to their gender differed significantly in favor of female students and students with teacher woman; that the levels of responsibility of the students according to their marital status differ significantly in favor of the students whose teachers are single; it was concluded that the level of responsibility of the students according to the type of school they attended and the level of responsibility of the students did not. The findings were discussed in the light of the literature and suggestions for new investigations were given.

Keywords: Responsibility, value, primary school, social studies

${ }^{1}$ Bu çalışma, birinci yazarın danışmanlığındaki ikinci yazarın yüksek lisans tezinden üretilmiştir.

${ }^{2}$ İstanbul Medeniyet Üniversitesi, Eğitim Bilimleri Fakültesi, İstanbul, Türkiye, https://orcid.org/0000-0002-3341-2576

${ }^{3}$ Sakarya Üniversitesi Vakfı Koleji, Sakarya, Türkiye, https://orcid.org/0000-0002-9697-7961

Atıf / Citation: Sağlam, H. İ. \& Kaplancı, B. (2020). İlkokul 4. sınıf öğrencilerinin sorumluluk düzeylerinin çeşitli değişkenler açısından incelenmesi. Kastamonu Education Journal, 28(2), 641-649. doi:10.24106/kefdergi.693440 


\section{Extended Abstract}

Introduction: Man is a responsible person to the extent that they possess, and to the extent that they fulfill their responsibilities. Man who deviates from other beings as he/ she creates value and lives in the value field; they have responsibility to him, his family and his community (Sağlam, 2019). Man's sense of responsibility is the most important feature that distinguishes him from other beings (Yeşil, 2003). Responsibility; it is a value that directs people to care for others, to support others, to make them reliable, to enable them to perform their duties in the best way (Lickona, 1991). In other words, responsibility; the person being able to act properly without supervision, correcting his or her behavior when acting improperly, and helping others to act appropriately (Duke and Jones, 1985). It determines the limits of human responsibilities and the roles in social life. The fact that the living environment is not a single person makes you accountable to yourself and to the people you live with while compelling you to always exist together with others. For this reason, responsibility firstly puts the responsibility of one's own reality and then another's reality (Yayla, 2014). The family, which is the child's first education center, is the place where the value education and moral sensibilities are laid. For this reason, it is very important that the emotions of children are nourished in the family environment, their interests are encouraged and supported in the home environment, and their skills and sensitivities are improved (Hökelekli and Gündüz, 2007).

Purpose: This study was conducted to determine the level of responsibility of the 4th grade students in elementary school. In addition, it was aimed to determine whether the levels of responsibility of primary school 4th grade students differ in terms of gender of the students, gender of teachers, teachers' marital status, type of school in which students continue, and the type of family.

Method: This study was conducted using relational screening model. "Screening models are the research models that aim to collect data to determine the certain properties of a group." (Büyüköztürk, Kılıç Çakmak, Akgün, Karadeniz, \& Demirel, 2014). The study group of the research consists of 844 fourth grade students (417 girls and 427 boys) attending primary school in Sakarya during 2017-2018 academic year. The study group was chosen from the state and private schools in Adapazarı and Serdivan districts of Sakarya province via convenience sampling method. The data of this study was collected using "Personal Information Form" and "Responsibility Scale (RS)." "Responsibility Scale (RS)" which is a likert type scale with 24 items was developed by Golzar (2006) to determine the responsibility levels of the primary school students. The students were asked to choose one of the options for each item as (1) Never, (2) Sometimes, (3) Always. While the maximum score of the scale is 72, the minimum score can be 24.

Discussion and Result: In the research, it was concluded that the responsibility levels of the primary school students were close to the upper level. This result is similar to the research results of Şahan (2011). Karakuş, Kartal and Çağlayan (2016) stated that students are appreciated when they fulfill their responsibilities and feel happy and reliable; when they did not fulfill the behaviors they were responsible for, they came to the conclusion that they experienced a feeling of sadness, disgust, discomfort, unhappiness, anxiety and failure. It was observed that the level of responsibility of the students who participated in the study differed significantly in favor of female students and female students' teachers. It is thought that culture and socialization process can be effective in the high level of responsibility of female students and teachers. This result is similar to Golzar's (2006) study that female students' level of responsibility is higher than that of male students. It was seen that the level of responsibility of the students participating in the study according to their marital status differed significantly in favor of the students who were single. It is thought that the level of responsibility of the students whose bachelors are single, may be related to the fact that single teachers can devote more time to their students and give more responsibility to their students. It was observed that the level of responsibility of the students participating in the study did not differ significantly according to the school and family types. In this case, students should attend private or public school; it has shown that having a large or nuclear family has no effect on their level of responsibility. In contrast to this study, Duruhan and Demir (2005) concluded that public schools are more effective than private schools in raising the motivation of students and increasing the motivation of students. 


\section{Giriş}

İnsan; sahip oldukları ölçüsünde sorumlu, sorumluluklarını yerine getirdiği ölçüde de değerli bir varlıktır. Değer üretmesi ve değer alanında yaşaması itibariyle diğer varlıklardan ayrılan insanın; kendisine, ailesine ve içinde bulunduğu topluma karşı sorumlulukları vardır (Sağlam, 2019). İnsanın sorumluluk duygusuna sahip olması, onu diğer varlıklardan ayıran en önemli özelliğidir (Yeşil 2003). Sorumluluk; insanı başkalarını önemsemeye, başkalarına destek olmaya yönelten, güvenilir kılan, insanın görevlerini en iyi şekilde yerine getirmesini sağlayan bir değerdir (Lickona, 1991). Başka bir ifadeyle sorumluluk; kişinin denetim olmaksızın düzgün davranması, uygunsuz davrandığında kendi davranışını düzeltebilmesi, davranışlarının sonuçlarına katlanabilmesi ve başkalarının uygun davranmalarına yardımcı olabilmesidir (Duke ve Jones, 1985). Insanın sorumluluklarının sınırını, toplumsal hayattaki rolleri belirler. Yaşama ortamının tek kişilik olmaması, insanı her zaman başkalarıyla birlikte var olmaya mecbur ederken kendine ve birlikte yaşadığı kişilere karşı sorumlu kılar. Bu nedenle sorumluluk bireye ilk önce kendi gerçekliğinin daha sonra da bir başkasının gerçekliğinin sorumluluğunu yükler (Yayla, 2014).

Sorumluluk, erken çocukluk dönemlerinden başlayarak çocuğun yaşına, cinsiyetine ve gelişim düzeyine uygun olarak gelişim görevlerini yerine getirmesidir (Yavuzer, 1997). Çocuğun ilk eğitim yeri olan aile, değer eğitiminin ve ahlaki duyarlılıkların temelinin atıldığı yerdir. Bu nedenle çocukların duygularının aile ortamında beslenip geliştirilmesi, ilgilerinin ev ortamında teşvik edilip desteklenmesi, yeteneklerinin ve duyarlılıklarının geliştirilmesi son derece önemlidir (Hökelekli ve Gündüz, 2007). Çocuğun okula başlamasıyla birlikte okulda kazandırılan değerler ile aile ortamında kazandırılan değerlerin tutarlılık göstermesi gerekir. Çocuğun psikososyal gelişiminde başarı ve özgüven için önkoşul niteliği taşıyan sorumluluk, toplum bilincinin yerleştirilmesinde de oldukça önemli ve etkilidir. Hayatın her alanında doyum elde etmenin yolu, kişinin sorumluluklarını yerine getirmesiyle mümkündür (Tepecik, 2008). "Sorumluluk, doğuştan gelen bir duygu olmayıp sonradan, uygun koşulların sağlanmasıyla kazanılabilmektedir. Sorumluluğun gelişmesi için insanın sorumluluk alabileceği bir ortamda yetişmesi gerekir. Kişiye seçim yapma ve yaptığı seçimin sonuçlarından sorumlu olma fırsatı verilmediğinde sorumluluk duygusunun gelişmesi güçleşebilir" (Cüceloğlu, 2002: 211). Sorumluluk duygusunun gelişmemesi, bireylerin karar almaktan ve sorumluluk üstlenmekten kaçınmasına neden olabilir. Bu durum bireyin üstlenmesi gereken sorumluluklarını başkalarının üstlenmesine ve yerine getirmesine yol açabilir (Önal, 2005). Kişinin sorumluğunu yerine getirmemesi bir sorumsuzluk, dahası bir saygısızlık örneği olarak da düşünülebilir. Sorumluluğunu bir başkasına devrederek sorumluluktan kaçmaya çalışan kişinin, aynı şeyin kendisine yapılmasından hoşlanması beklenemez. İnsanın sorumluluğunu bir başkasına yüklemeye çalışması bir insan hakkı ihlali olarak da değerlendirilebilir (Sağlam, 2017).

Ailede çocuğun gelişim düzeyine uygun, başarabileceği sorumluluklar verilmesi onun gelişimi açısından oldukça önemlidir. Sorumluluk sahibi çocuklar; kaynaklarını bilinçli kullanabilen, kendi kararlarını verebilen, duygularının, düşüncelerinin ve davranışlarının sonuçlarını kabul edebilen, başkalarının hak ve sorumluluklarını bilebilen, kendi eylemlerinin sorumluluğunu üstlenebilen, mutlu, çevresiyle uyumlu, çalışkan birey olarak tanımlanabilir. Buna karşın sorumsuz çocuklar; üstüne düşen görevleri yerine getirmeyen, hatalarını başkalarına yükleme eğiliminde olan, duygu, düşünce ve eylemlerinin arkasında durmayan, kendine karşı sorumluluklarını yerine getirmediği gibi başkalarına karşı da sorumluluklarını yerine getirmeyen, tembel, uyumsuz ve sorun oluşturan bireyler olarak ifade edilebilir (Güner ve Selçuk, 2004). Bireylerin düşüncelerini ve davranışlarını kabul ederek sonuçlarına katlanabilmeleri, yaşamlarının her döneminde üstlendikleri sorumlulukları yerine getirebilmeleri, bilinçli seçim yapabilmeleri, karar verebilmeleri, sorumluluklarını üstlenmeleri, eylemleriyle hayatı yaşanabilir kılabilmeleri, toplum hayatına uyum sağlayarak mutlu bireyler olabilmeleri, görevlerini yerine getirebilmeleri, uygun bir sosyal çevreye sahip olabilmeleri ve sağlıklı birey olarak hayatlarına devam edebilmeleri için sorumluluk eğitimine ihtiyaç vardır (Önal, 2005).

Alanyazında sorumlulukla ilgili çalışmaların (Aladağ, 2012; Aydoğan ve Gündoğdu, 2015; Golzar, 2006; Gündüz ve Özerbaş, 2015; Karakuş, Kartal ve Çağlayan, 2016; Önal, 2005; Qin, Qian ve Chen, 2011; Sağlam ve Kaplancı, 2018; Such ve Walker, 2004; Şahan, 2011; Taşdemir ve Dağıstan, 2014; Yontar, 2007) yer aldığı görülmektedir. Aladağ (2012), öğrencilerin cinsiyetlerinin ve aile öğrenim düzeylerinin sorumluluklarını bilişsel düzey açısından etkilemediği sonucuna ulaşmıştır. Aydoğan ve Gündoğdu (2015) araştırmalarında ders içi sorumluluk, ders dışı sorumluluk, dayanışma sorumlulukları ve aile içi sorumluluk olmak üzere dört alt boyuttan oluşan eylem planı hazırlamışlardır. Öğrencilerin en çok istedikleri görevleri yerine getirdiklerini, istedikleri görevlerde daha sorumlu davrandıklarını, ödev yapma davranışı az olan öğrencilerin istenmeyen davranışlarında azalma meydana geldiğini gözlemlemişlerdir. Golzar (2006), öğrencilerin sorumluluk düzeylerinin cinsiyet, akademik başarı ve denetim odağı bakımından farklılaşıp farkılış̧madığını incelemiş ve kızların erkeklere göre, akademik başarısı yüksek olan öğrencilerin başarısı düşük olanlara göre, içten denetimli öğrencilerin diğerlerine göre daha çok sorumluluk sahibi 
olduğunu belirlemiştir. Gündüz ve Özerbaş (2015) araştırmalarında proje tabanlı sorumluluk değeri öğretiminde, deney grubundaki öğrencilerin öz bakım ve görev bilinci anlamında tutum puanlarının yükseldiğini, anlamlı ve kalıcı öğrenmelerin sağlandığını tespit etmişlerdir. Karakuş, Kartal ve Çağlayan (2016), öğrenciler sorumluluklarını yerine getirdiklerinde takdir edildiklerini, kendilerini mutlu ve güvenilir hissettiklerini; sorumlu oldukları davranışları yerine getirmediklerinde ise üzüntü, gözden düşme korkusu, huzursuzluk, mutsuzluk, kaygı ve başarısızlık duygusu yaşadıklarını tespit etmişlerdir. Önal (2005) sorumluluk eğitim programının dokuzuncu sınıf öğrencilerinin sorumluluk düzeylerini olumlu yönde etkilediğini; Qin, Qian ve Chen (2011), sorumluluk duygusunun akademik fonksiyonu etkilediği, okulda etkileşim ve performansı artırdığını; Sağlam ve Kaplancı (2018), öğrencilerin sorumluluk düzeyleri ile okul doyumu ve okula bağlanmaları arasında pozitif yönde ve anlamlı bir ilişkinin olduğunu, öğrencilerin sorumluluklarının düzen ve sorumluluk algılarına göre anlamlı bir şekilde farklılaştığını belirlemişlerdir. Such ve Walker (2004) çalışmalarında sorumluluk kavramını analiz ederek, sorumluluğun dürüstlük ve adaletli olma değerine vurgu yaptığı; Şahan (2011), öğrencilerin kendilerini iyi düzeyde sorumlu gördükleri sonucuna ulaşmışlardır. Taşdemir ve Dağıstan (2014) sorumluluk ve eğitim ilişkisini, ebeveynlerin çocuklarının sorumluluk bilinci konusundaki görüşlerini ele aldıkları araştırmalarında, başarılı öğrencilerin her türlü sorumluluğu yerine getirdikleri ve ebeveynlerin bilgilendirme, hatırlatma, takip ve geri bildirim yöntemlerini kullandıklarını belirlemişlerdir. Yontar (2007) çalışmasında öğretmenlerin yerine getirilmeyen sorumluluklarla baş etmede ceza içeren yöntemlere başvurduklarını ve bu yöntemlerin kısa süreli etkili olduğunu ortaya koymuştur. Alanyazında yer alan çalışmalardan farklı olduğu düşünülerek bu araştırmanın temel amacı, ilkokul 4. sınıf öğrencilerinin sorumluluk düzeylerinin incelenmesi olarak belirlenmiştir. Bu amaçla aşağıdaki sorulara cevap aranmıştır:

1. Öğrencilerin cinsiyetleriyle sorumluluk düzeyleri arasında anlamlı bir farklılık var mıdır?

2. Öğretmenlerin cinsiyetleri ile öğrencilerin sorumluluk düzeyleri arasında anlamlı bir farklılık var mıdır?

3. Öğretmenlerin medeni durumları ile öğrencilerin sorumluluk düzeyleri arasında anlamlı bir farklılık var mıdır?

4. Okul türleri ile öğrencilerin sorumluluk düzeyleri arasında anlamlı bir farklılık var mıdır?

5. Aile türleri ile öğrencilerin sorumluluk düzeyleri arasında anlamlı bir farklılık var mıdır?

\section{Yöntem}

$\mathrm{Bu}$ araştırma, tarama yöntemiyle yapılmıştır. Tarama, bir grubun belirli özelliklerini belirlemek için verilerin toplanmasını amaçlayan çalışmalara denir (Büyüköztürk, Kılıç Çakmak, Akgün, Karadeniz ve Demirel, 2014). Tarama, geçmişte ya da halen var olan bir durumu olduğu şekliyle betimlemeyi amaçlayan araştırma yaklaşımlarıdır. Araştırmaya konu olan olay, birey ya da nesne, kendi koşulları içinde ve olduğu gibi tanımlanmaya çalışılır (Karasar, 2009).

\section{Çalışma Grubu}

Araştırmanın çalışma grubunu, 2017-2018 eğitim öğretim yılında Sakarya ilinde öğrenim gören 417’si (\%49) kız, 427'si (\%51) erkek olmak üzere toplam 844 ilkokul 4 üncü sınıf öğrencisi oluşturmaktadır. Çalışma grubu Sakarya ilinin Adapazarı ve Serdivan ilçelerindeki devlet ve özel okullarından uygun örnekleme yöntemiyle seçilmiştir. Uygun örnekleme, yakın çevrede bulunan, ulaşılması kolay ve araştırmaya gönüllü olarak katılmak isteyen bireyler üzerinde yapılan örnekleme olarak tanımlanmaktadır (Ekiz, 2009). Tablo 1'de araştırmaya katılan öğrencilerin demografik özellikleri yer almaktadır.

Tablo 1. Araştırmaya Katılan Öğrencilerin Demografik Özellikleri

\begin{tabular}{llll}
\hline \multirow{2}{*}{ Değişken } & Tür & $f$ & $\%$ \\
\hline \multirow{2}{*}{ Cinsiyet } & Kız & 417 & 49 \\
& Erkek & 427 & 51 \\
\hline \multirow{2}{*}{ Öğretmenin cinsiyeti } & Kadın & 577 & 32 \\
\hline \multirow{2}{*}{ Öğretmenin medeni durumu } & Erkek & 267 & 84 \\
& Evli & 707 & 16 \\
\hline \multirow{2}{*}{ Okul türü } & Bekâr & 137 & 28 \\
\hline \multirow{2}{*}{ Aile türü } & Özel & 239 & 72 \\
\hline
\end{tabular}


Tablo 1 incelendiğinde araştırmaya katılan öğrencilerin \%49'unun kız, \%51'inin erkek olduğu; \%68'inin öğretmeninin kadın, \%32'sinin erkek olduğu; öğretmenlerin \%84'ünün evli, \%16'sının bekâr olduğu görülmektedir. Araştırmaya katılan ilkokul öğrencilerinin \%28'inin özel okulda, \%72'sinin devlet okulunda öğrenim gördüğü; \%22'sinin geniş, \%78'inin çekirdek aileye sahip olduğu görülmektedir.

\section{Veri toplama araçları}

Bu araştırmada veriler “Kişisel Bilgi Formu” ve "Sorumluluk Ölçeği (SÖ)” ile elde edilmiştir. Kişisel Bilgi Formu’nda öğrencilerin cinsiyetleri, öğretmenlerin cinsiyetleri, öğretmenlerin medeni durumları, öğrencilerin okul ve aile türleri yer almaktadır. İlkokul öğrencilerinin sorumluluk düzeyini ölçmek amacıyla Golzar (2006) tarafından geliştirilen Sorumluluk Ölçeği (SÖ), 24 maddelik 3'lü likert tipi bir ölçektir ve ölçek Türkiye'de geliştirilmiştir. Geçerlilik çalışmaları bağlamında ölçek; kapsam, yapı ve paralel ölçek geçerliliği yönünden incelenmiştir. Kapsam geçerliliği, uzman görüşleriyle sağlanmıştır. Yapı geçerliliği açımlayıcı faktör analizi ile belirlenmiş olan ölçeğin madde faktör yükleri .32 ile .55 arasında değişmektedir. İç tutarlılık katsayısı hesaplandıktan sonra ölçeğin paralel ölçek geçerliliği Ahlaki Olgunluk Ölçeği ile incelenmiştir. Ahlaki Olgunluk Ölçeği, Sorumluluk Ölçeği ile benzer ve yakın maddeler içermesi nedeniyle kullanılmıştır. Her iki ölçek arasındaki ilişki katsayısı .53 olarak hesaplanmış, pozitif ve .01 düzeyinde anlamlı bir ilişki bulunmuştur. Sorumluluk Ölçeği'nin güvenirlik hesaplamalarında Cronbach Alfa iç tutarlık katsayısının .83 olduğu belirlenmiştir. Bu araştırmada, Cronbach Alfa iç tutarlık katsayısı .78 olarak hesaplanmıştır. Öğrencilerden her bir maddenin karşısında yer alan (1) Hiçbir zaman, (2) Bazen, (3) Her zaman seçeneklerinden birini seçmeleri istenmiştir. Ölçekten alınabilecek en yüksek puan 72, en düşük puan 24'tür (Golzar, 2006).

\section{Verilerin Toplanması ve Analizi}

Ölçme araçları Sakarya ilinin, Adapazarı ve Serdivan ilçelerindeki okullara Etik Kurulu Raporu ve araştırma izinleri alındıktan sonra araştırmacılar tarafından ulaştııımıştır. Okul yönetimiyle görüşme yapıılıktan sonra ölçme araçları ilkokul 4. sınıf öğrencilerine uygulanmıştır. Öğrencilere dağıtılan 950 ölçme aracından 940'ı geri dönmüş, bunlardan 96'sı amaca uygun olarak doldurulmadığı için değerlendirme dışında tutulmuştur. Değerlendirmeler 844 ölçme aracı üzerinden yapılmıştır. Elde edilen verilere uygulanacak testleri belirlemek amacıyla yapılan Kolmogorov-Smirnov testi sonucunda dağılımlarının normal olduğu sonucuna ulaşılmıştır. Bu nedenle öğrencilerin cinsiyetleri, öğretmenlerin cinsiyetleri, öğretmenlerin medeni durumları, öğrencilerin okul türleri ve aile türleri kategorilerinde kategori düzeyi iki olduğundan değişkenlerde anlamlı bir şekilde farklılaşma olup olmadığını belirlemek için t-testi yapılmıştır.

\section{Bulgular}

Bulgular başlığı altında, bulgular araştırmanın alt problemlerine göre sırasıyla ele alınmıştır.

Tablo 2. Sorumluluk Ölçeğine İlişkin Betimsel Veriler

\begin{tabular}{cccccc}
\hline Ölçek & $\mathrm{N}$ & Minimum & Maksimum & $\overline{\mathrm{X}}$ & ss \\
\hline Sorumluluk & 844 & 53.00 & 72.00 & 65.96 & 4.46 \\
\hline
\end{tabular}

Tablo 2'de öğrencilerin “Sorumluluk Ölçeği”nden aldıkları minimum, maksimum puanlar ile aldıkları puanların aritmetik ortalamaları ve standart sapmalar yer almaktadır. Tablo 2 incelendiğinde öğrencilerin aldıkları puanların aritmetik ortalamasının Sorumluluk Ölçeği'nden alabilecekleri maksimum puana yakın olduğu görülmektedir.

Tablo 3. Öğrencilerin Cinsiyetlerine Göre Sorumluluk Düzeylerinin Farklılaşıp Farklılaşmadığına ilişskin t Testi Sonuçları

\begin{tabular}{lllllll}
\hline Cinsiyet & $\mathrm{N}$ & $\overline{\mathrm{X}}$ & $\mathrm{ss}$ & $\mathrm{t}$ & $\mathrm{sd}$ & $\mathrm{p}$ \\
\hline KIz & 417 & 66.71 & 4.39 & 4.81 & 842 & .000 \\
Erkek & 427 & 65.24 & 4.40 & & & \\
\hline
\end{tabular}

Tablo 3 incelendiğinde araştırmaya katılan öğrencilerin cinsiyetlerine göre sorumluluk düzeylerinin kız öğrenciler $\left[\mathrm{t}_{(842)}=4.81 ; p<.05\right]$ lehine anlamlı bir şekilde farklılaştığı görülmektedir. Bu durum kız öğrencilerin, erkek öğrencilere göre sorumluluk düzeylerinin daha yüksek olduğunu göstermektedir. 
Tablo 4. Öğretmenlerin Cinsiyetlerine Göre Öğrencilerin Sorumluluk Düzeylerinin Farklılaşıp Farklılaşmadığına iliş̧kin $t$ Testi Sonuçları

\begin{tabular}{cllllll}
\hline Öğretmenin Cinsiyeti & $\mathrm{N}$ & $\overline{\mathrm{X}}$ & $\mathrm{ss}$ & $\mathrm{t}$ & $\mathrm{sd}$ & $\mathrm{p}$ \\
\hline Kadın & 577 & 66.21 & 4.36 & -2.333 & 842 & .020 \\
Erkek & 267 & 65.44 & 4.65 & & & \\
\hline
\end{tabular}

Tablo 4 incelendiğinde araştırmaya katılan öğrencilerin öğretmenlerinin cinsiyetlerine göre sorumluluk düzeylerinin öğretmeni kadın olan öğrenciler $\left[\mathrm{t}_{(842)}=-2.333 ; p<.05\right]$ lehine anlamlı bir şekilde farklılaştığı görülmektedir. Bu durum öğretmeni kadın olan öğrencilerin, öğretmeni erkek olan öğrencilere göre sorumluluk düzeylerinin daha yüksek olduğunu göstermektedir.

Tablo 5. Öğretmenlerin Medeni Durumlarına Göre Öğrencilerin Sorumluluk Düzeylerinin Farklılaşıp Farklılaşmadığına İlişkin t Testi Sonuçları

\begin{tabular}{llllcll}
\hline Medeni Durum & $\mathrm{N}$ & $\overline{\mathrm{X}}$ & $\mathrm{ss}$ & $\mathrm{t}$ & $\mathrm{sd}$ & $\mathrm{p}$ \\
\hline Evli & 707 & 65.81 & 4.46 & -2.347 & 842 & .019 \\
Bekâr & 137 & 66.79 & 4.43 & & & \\
\hline
\end{tabular}

Tablo 5 incelendiğinde araştırmaya katılan öğrencilerin öğretmenlerinin medeni durumlarına göre sorumluluk düzeylerinin öğretmeni bekâr olan öğrenciler $\left[\mathrm{t}_{(842)}=-2.347 ; \quad p<.05\right]$ lehine anlamlı bir şekilde farklılaştığı görülmektedir. Bu durum öğretmeni bekâr olan öğrencilerin, öğretmeni evli olan öğrencilere göre sorumluluk düzeylerinin daha yüksek olduğunu göstermektedir.

Tablo 6. Öğrencilerin Devam Ettikleri Okul Türüne Göre Sorumluluk Düzeylerinin Farklılaşıp Farklılaşmadığına ilişkin t Testi Sonuçları

\begin{tabular}{lllllll}
\hline Okul Türü & $\mathrm{N}$ & $\overline{\mathrm{X}}$ & $\mathrm{ss}$ & $\mathrm{t}$ & $\mathrm{sd}$ & $\mathrm{p}$ \\
\hline Özel & 239 & 65.52 & 4.43 & -1.823 & 842 & .069 \\
Devlet & 605 & 66.14 & 4.47 & & & \\
\hline
\end{tabular}

Tablo 6 incelendiğinde araştırmaya katılan öğrencilerin devam ettikleri okul türüne göre sorumluluk düzeylerinin $\left[\mathrm{t}_{(842)}=-1.823 ; p>.05\right]$ anlamlı bir şekilde farklılaşmadığı görülmektedir. Bu durum öğrencilerin özel ya da devlet okuluna devam etmelerinin sorumluluk düzeylerine bir etkisi olmadığını göstermektedir.

\section{Sonuçları}

Tablo 7. Öğrencilerin Aile Türlerine Göre Sorumluluk Düzeylerinin Farklılaşıp Farklılaşmadığına ilişskin t Testi

\begin{tabular}{lllllll}
\hline Aile Türü & $\mathrm{N}$ & $\overline{\mathrm{X}}$ & $\mathrm{ss}$ & $\mathrm{t}$ & $\mathrm{sd}$ & $\mathrm{p}$ \\
\hline Geniş & 183 & 66.05 & 4.58 & .326 & 842 & .744 \\
Çekirdek & 661 & 65.93 & 4.44 & & & \\
\hline
\end{tabular}

Tablo 7 incelendiğinde araştırmaya katılan öğrencilerin aile türüne göre sorumluluk düzeylerinin $\left[\mathrm{t}_{(842)}=.326\right.$; p>.05] anlamlı bir şekilde farklılaşmadığı görülmektedir. Bu durum öğrencilerin geniş ya da çekirdek aileye sahip olmalarının sorumluluk düzeylerine bir etkisi olmadığını göstermektedir.

\section{Tartışma, Sonuç ve Öneriler}

Araştırmada ilkokul öğrencilerinin sorumluluk düzeylerinin üst seviyeye yakın olduğu sonucuna ulaşılmıştır. Bu sonuç Şahan'ın (2011) araştırma sonuçlarıyla benzerlik göstermektedir. Söz konusu araştırmada beşinci ve sekizinci sınıf öğrencilerinin ders programlarındaki sorumluluk kazanımlarını gerçekleştirme düzeylerine ilişkin olarak öğretmen ile öğrenci görüşlerinin karşılaştırılmasında öğrenciler lehine anlamlı düzeyde farklılıklar bulunmuş; kendileriyle ilgili olarak öğrenciler, öğretmenlerine göre kendilerinin daha sorumluluk sahibi olduklarını belirtmiş; beşinci sınıf öğrencileri kendilerine göre sorumluluk düzeylerinin "çok iyi” olduğunu ifade etmişlerdir. Ünal (2011), öğretmenlerin mesleki alanlarına göre değer tercihlerinde, tüm alan öğretmenlerinin saygı, dürüstlük, sevgi ve bilimsellik ve sorumluluk gibi değerlerini ilk sıralarda tercih ettiklerini belirlemiştir. Dilmaç, Kulaksızoğlu ve Ekşi 
(2007), insani değerler eğitimi grup rehberliğine katılan öğrencilerin insani değerler ölçeğinin sorumluluk, barışçı olma, saygı, dürüstlük ve hoşgörü düzeylerinin eğitim programı sonunda anlamlı bir şekilde artış gösterdiği sonucuna ulaşmışlardır. Karakuş, Kartal ve Çağlayan (2016), öğrenciler sorumluluklarını yerine getirdiklerinde takdir edildikleri, kendilerini mutlu ve güvenilir hissettikleri; sorumlu oldukları davranışları yerine getirmediklerinde ise üzüntü, gözden düşme korkusu, huzursuzluk, mutsuzluk, kaygı ve başarısızlık duygusu yaşadıkları sonucuna ulaşmışlardır. Bu sonuçlardan farklı olarak Aslan (2007) ve Sezer (2008), araştırmalarında öğretmenlerin en fazla kazandırmak istedikleri değerin sorumluluk değeri olmasına rağmen, en az kazandırılan değerin de sorumluluk değeri olduğunu bulmuşlardır. Bütün bu sonuçlar öğrencilerin sorumluluk düzeylerine yönelik olarak iyimser bir durum ortaya koymakla birlikte velilerin ve öğretmenlerin öğrencilerin sorumluluklarını yerine getirmelerine yönelik olarak göz ardı edilemeyecek endişeler taşıdıkları gerçeğini ortadan kaldırmamaktadır. Velilerin ve öğretmenlerin öğrencilerden farkı düşünmesi, öğrencilerin kendileriyle ilgili sübjektif değerlendirme yapmalarıyla ilişkisi olabileceği gibi sorumluluk anlayışlarındaki farklılığın bir sonucu da olabileceği gerçeği göz ardı edilmemelidir.

Araştırmaya katılan öğrencilerin cinsiyetlerine göre sorumluluk düzeylerinin kız öğrenciler ve öğretmeni kadın olan öğrenciler lehine anlamlı bir şekilde farklılaştığı görülmüştür. Bu da kız öğrencilerin sorumluluk düzeylerinin erkek öğrencilere göre daha yüksek olduğunu göstermektedir. Kız öğrencilerin ve öğretmeni kadın olan öğrencilerin sorumluluk düzeylerinin yüksek olmasında kültürün ve sosyalleşme sürecinin etkili olabileceği düşünülmektedir. Toplumsal roller bakımından kadınlara yüklenen sorumlulukların erkeklere oranla daha fazla olması kız öğrencilerin sorumluluk düzeylerine olumlu yönde etkilemiş olabilir. Bu sonuç Golzar'ın (2006), kız öğrencilerin sorumluluk düzeylerinin erkek öğrencilere göre daha yüksek olduğu yönündeki bulgusu ile benzerlik göstermektedir. Şahan (2011), ilköğretim ders programlarındaki sorumluluk eğitimine dönük kazanımların gerçekleme düzeyleri ile ilgili araştırmasında, beşinci sınıf öğrencilerinin sorumluluk algılarının "kişisel sorumluluk" ve "yasal sorumluluk" boyutlarında kızlar lehine farklılaştığını belirlemiştir. Akbaş (2004), sekizinci sınıf öğrencilerinin ilköğretim okulları genel hedeflerinde belirtilen değerlere ulaşma düzeyleri üzerine yaptığı çalışmada, kız ve erkek öğrencilerin "sorumluluk sahibi olmak" değerine ilişkin puanları arasında kız öğrenciler lehine anlamlı düzeyde farklılık bulmuştur. Oğuz (2012), Altunay ve Yalçınkaya (2011) tarafından gerçekleştirilen çalışmada da öğretmen adaylarının cinsiyetlerine göre benimsedikleri değerler karşılaştırıldığında, erkek öğretmen adaylarına göre kadın öğretmen adaylarının tüm değer boyutlarına daha fazla önem verdikleri belirlenmiştir. Keskin ve Sağlam (2014), insani değerlerle ilgili yaptıkları araştırmada sınıf öğretmeni adaylarının cinsiyetlerine göre entelektüel değerler, maneviyat ve özgürlük boyutlarında kadınlar lehine anlamlı bir farklılık tespit etmişlerdir. Bu sonuçlar Ersoy'un (2009) temel değerler konusunda cinsiyete göre farklılıkların çoğunlukla kızlar lehine olması, kız öğrencilerin erkek öğrencilere göre daha duygusal olmasından kaynaklandığı yönündeki görüşünü destekler niteliktedir. Bu çalışmalardan farklı olarak Aladağ (2012), öğrencilerin cinsiyetlerinin sorumluluk düzeylerini bilişsel düzey açısından etkilemediğini; Özen (2009), yaptığı çalışmada ilköğretim sekizinci sınıf öğrencilerinin cinsiyetlerinin kişisel ve sosyal sorumluluk düzeylerini etkilemediğini belirlemişlerdir. Aynı şekilde Şahan (2011), sekizinci sınıf öğrencilerinin sorumluluk algılarının cinsiyetlerine göre farklılaşmadığı sonucuna ulaşmıştır.

Araştırmaya katılan öğrencilerin öğretmenlerinin medeni durumlarına göre sorumluluk düzeylerinin öğretmeni bekâr olan öğrenciler lehine anlamlı bir şekilde farklılaştığı görülmüştür. Bu durum öğretmeni bekâr olan öğrencilerin, öğretmeni evli olan öğrencilere göre sorumluluk düzeylerinin daha yüksek olduğunu göstermektedir. Öğretmeni bekâr olan öğrencilerin sorumluluk düzeylerinin daha yüksek olması, bekâr öğretmenlerin evli öğretmenlere göre öğrencilerine daha çok zaman ayırabilmeleriyle ilişkili olabilir. Bekâr öğretmenlerin evli öğretmenlere göre sorumluluklarının daha az olması öğrencilerine daha fazla zaman ayırabilmelerine imkân verebilir. Böylece bekâr öğretmenler bu imkânı öğrencilerine sorumluluk kazandırmak için değerlendirmiş olabilirler.

Araştırmaya katılan öğrencilerin okul ve aile türlerine göre sorumluluk düzeylerinin anlamlı bir şekilde farklılaşmadığı görülmüştür. Bu durum öğrencilerin özel ya da devlet okuluna devam etmelerinin; geniş ya da çekirdek aileye sahip olmalarının sorumluluk düzeylerine bir etkisi olmadığını göstermiştir. Bu sonuç dikkat çekici bulunmuştur. Çünkü özel okula devam eden öğrencilerin devlet okuluna devam eden öğrencilere göre, göreceli de olsa, daha konforlu bir hayat yaşayabileceklerini, rahatlarına daha düşkün olabileceklerini düşündürmektedir. Bu arada bazı velilerin imkânlarını zorlayarak çocuklarını özel okula gönderdiğine ilişkin yaygın bir kanaati göz ardı etmemek gerekir. Her çocuk özel olmakla birlikte bazı velilerin kendi çocuklarına yönelik olarak daha özel olduğunu düşünmesi, sorumluluk açısından bazı sorunlara yol açabilmektedir. Bu ve benzeri düşüncelere sahip velilerin çocuklarının sorumluluklarını kendilerinin üstlenmesi aslında önemli bir sorun ve sorunların kaynağı olarak düşünülmelidir. Böyle bir düşünce ve uygulama, çocuklarda sorumluluk bilincinin gelişmesini engellemekle kalmaz, ciddi bir biçimde değer erozyonuna da neden olabilir. Benzer şekilde geniş ailede yaşayan çocukların dede ya da nine gibi aile büyükleri tarafından şımartılması sonucunda çocukların sorumluluk bilinci kazanması sekteye uğrayabilir. Bu araştırmadan farklı olarak Duruhan ve Demir (2005), öğrencilerde sorumluluk alma isteği uyandırmada ve 
öğrencilerin motivasyonlarını arttırmada devlet okullarının özel okullara kıyasla daha etkili olduğunu belirlemişlerdir. Araştırmanın bulguları ışı̆̆ında şu önerilere yer verilebilir:

1. İlkokul öğrencilerinin sorumluluk düzeylerinin üst seviyeye yakın olması iyimser bir durum olarak değerlendirilebilir. Bununla birlikte öğrencilerin sorumluluklarına ilişkin öğrencilere, velilere ve öğretmenlere yönelik karşılaştırmalı araştırmalar yapılarak farklı açıdan durum tespit edilebilir.

2. Erkek ve öğretmeni erkek olan öğrencilerin sorumluluk düzeylerini artırmaya yönelik çalışmalar yapılabilir.

3. Öğretmeni bekâr olan öğrencilerin sorumluluk düzeylerinin öğretmeni evli olan öğrencilere göre yüksek olması nedeniyle evli öğretmenlerin de öğrencilerinin sorumluluk düzeylerinin artırılmasında farkındalık kazanmaları sağlanabilir.

\section{Kaynakça}

Akbaş, O. (2004). Türk Milli Eğitim sisteminin duyuşsal amaçlarının ilköğretim II. kademedeki gerçekleşme derecesinin değerlendirilmesi. (Yayımlanmamış doktora tezi). Gazi Üniversitesi Eğitim Bilimleri Enstitüsü, Ankara.

Aladağ, S. (2012). ìlköğretim sosyal bilgiler öğretiminde değer eğitimi yaklaşımlarının öğrencilerin sorumluluk değerini bilişşel düzeyde kazanmalarına etkisi. Türkiye Sosyal Araştırmalar Dergisi, 16(1), 123-146.

Altunay, E. ve Yalçınkaya M. (2011). Öğretmen adaylarının bilgi toplumunda değerlere ilişkin görüşlerinin bazı değişkenler açısından incelenmesi. Kuram ve Uygulamada Eğitim Yönetimi, 17(1), 5-28.

Aslan, R. (2007). Öğretmen görüşlerine göre ilköğretim birinci basamaktaki öğrencilerin temel bilgi, beceri ve değerler kazanma düzeyleri. (Yayımlanmamış yüksek lisans tezi). Anadolu Üniversitesi, Eskişehir.

Aydoğan, R. ve Gündoğdu, K. (2015). The reflections of a responsibility program prepared for primary school students: An action research. Eğitimde Kuram ve Uygulama, 11(3), 1061-1088.

Büyüköztürk, Ş., Kılıç Çakmak, E., Akgün, Ö. E., Karadeniz, Ş. ve Demirel, F. (2014). Bilimsel Araştırma Yöntemleri. Ankara: Pegem Akademi Yayınları.

Cüceloğlu, D. (2002). Anlamlı ve Coşkulu Bir Yaşam Için Savaşçı. İstanbul. Remzi Kitabevi Yayınları.

Dilmaç, B., Kulaksızoğlu, A. ve Ekşi, H. (2007). Bir grup fen lisesi öğrencisine verilen insani değerler eğitiminin insani değerler ölçeği ile sınanması. Kuram ve Uygulamada Eğitim Bilimleri, 7, 1221-1261.

Duruhan, K. ve Demir, S. (2005). Resmi ve özel ilköğretim okullarındaki eğitici kol çalışmalarının amaçlarına ulaşma düzeyine ilişkin öğrenci görüşleri. Erciyes Üniversitesi Sosyal Bilimler Enstitüsü Dergisi, 19, 175-185

Duke, D. L., \& Jones, V. F. (1985). What can schools do to foster student responsibility? Theory into Practice, 24(4), 277-285.

Ersoy, E. (2009). Cinsiyet kültürü içerisinde kadın ve erkek kimliği. Fırat Üniversitesi Sosyal Bilimler Dergisi, 19(2), 209230.

Ekiz, D. (2009). Bilimsel Araştırma Yöntemleri. Ankara: Anı Yayıncılık.

Golzar, A. F. (2006). Ilköğretim 5. sınıf öğrencilerine yönelik sorumluluk ölçeğinin geliştirilmesi ve sorumluluk düzeylerinin cinsiyet denetim odağı ve akademik başarıya göre incelenmesi. (Yayımlanmamış yüksek lisans tezi). Hacettepe Üniversitesi Sosyal Bilimler Enstitüsü, Ankara.

Güner, N. ve Selçuk, Z. (2004). Sınıf İçi Rehberlik Uygulamaları (4. Baskı). Ankara: Pegem Yayıncılık.

Gündüz, M. ve Özerbaş, M. A. (2015). Sorumluluk değerinin proje tabanlı öğrenmeyle öğretiminin ilköğretim 3. sınıf öğrencilerinin tutumlarına etkisi. Uluslararası Sosyal Araştırmalar Dergisi, 7(32), 520-532.

Hökelekli, H. ve Gündüz, T. (2007). Üstün yetenekli çocukların değer yönelimleri ve eğilimleri. Değerler ve Eğitimi. R. Kaymakcan, S. Kenan, H. Hökelekli, Ş. Arslan, M. Zengin (Ed.). İstanbul: Değerler Eğitimi Merkezi Yayınları.

Karakuş, C., Kartal, A. ve Çağlayan, K. T. (2016). İlkokul öğrencilerine göre sorumluluk. Ankara Üniversitesi Eğitim Bilimleri Fakültesi Dergisi, 49(1), 1-19.

Karasar, N. (2009). Bilimsel Araştırma Yöntemleri. Ankara: Nobel Yayın Dağıtım.

Keskin, U. ve Sağlam, H. İ. (2014). Sınıf öğretmeni adaylarının insani değerlere sahip olma düzeylerinin çeşitli değişkenler açısından incelenmesi. Sakarya University Journal of Education, 4(1), 81-101. 
Lickona, T. (1991). Educating And Character Education: How Our Schools Can Teach Respect And Responsibility. New York: Bantam Books.

Oğuz, E. (2012). Öğretmen adaylarının değerler ve değerler eğitimine ilişkin görüşleri. Kuram ve Uygulamada Eğitim Bilimleri, 12 (2), 1309-1325.

Önal, Ş. H. (2005). Bir sorumluluk eğitim programının lise dokuzuncu sınıf öğrencilerinin sorumluluk düzeylerine etkisi. (Yayımlanmamış yüksek lisans tezi). Uludağ Üniversitesi Sosyal Bilimler Enstitüsü, Bursa.

Özen, Y. (2009). Illköğretim 8. sınıf öğrencilerinin kişisel ve sosyal sorumluluk yordayıcılarının incelenmesi. (Yayımlanmamış doktora tezi). Atatürk Üniversitesi Sosyal Bilimler Enstitüsü, Erzurum.

Qin, L., Qian W., \& Chen, H. (2011). Changes in early adolescents' sense of responsibility to their parents in the united states and china: Implications for academic functioning. Child Development, 82(4), 1136-1151.

Sağlam, H. İ. (2017). Bir Değer ve Eğitim Merkezi Olarak Aile. Ankara: Pegem Akademi Yayınları.

Sağlam, H. I. ve Kaplancı, B. (2018). Examining the sense of responsibility of the primary school students in terms of school satisfaction and school attachment. Journal of Family Counseling and Education, 3(1), 1-16

Sağlam, H. İ. (2019). Karakter ve Değer Eğitimi. Ankara: Pegem Akademi Yayınları.

Sezer, T. (2008). Illköğretim 6. sınıf sosyal bilgiler dersinde sorumluluk değerinin öğretimine ilişkin öğretmen görüşleri. (Yayımlanmamış yüksek lisans tezi). Gazi Üniversitesi, Ankara.

Such, E., \& Walker, R. (2004). Being responsible and responsible beings: children's understanding of responsibility. Children \& Society, 18, 231-242.

Şahan, E. (2011). Illköğretim 5. ve 8. sınıf ders programlarındaki sorumluluk eğitimine dönük kazanımların gerçekleşme düzeyleri. (Yayımlanmamış yüksek lisans tezi). Ahi Evran Üniversitesi Sosyal Bilimler Enstitüsü, Kırşehir.

Taşdemir, M. ve Dağıstan, G. (2014). Çocuklara sorumluluk kazandırmada ebeveynlerin BHTG yaklaşımını uygulama durumları: Bir durum çalışması. Turkish Studies, 9(8), 47-71.

Tepecik, B. (2008) Sosyal bilgiler dersinde sorumluluk değerinin kazandırılmasına ilişkin öğretmen görüşleri. (Yayımlanmamış yüksek lisans tezi). Anadolu Üniversitesi Eğitim Bilimleri Enstitüsü, Eskişehir.

Ünal, F. (2011). Öğretmenlerin öğrencilerine kazandırmak istedikleri değerlere yönelik bir inceleme. Eğitim ve İnsani Bilimler Dergisi: Teori ve Uygulama, 2 (4), 3-24.

Yavuzer, H. (1997). Anne-Baba ve Çocuk. İstanbul: Remzi Kitabevi

Yayla, A. (2014). Etik bir talep: Sorumluluk eğitimi. Çağın Sorunları Karşısında Eğitim Sempozyumu Kitabı (s.317-326). Erzurum: Bayburt Üniversitesi Yayınları.

Yeşil, R. (2003). Sorumluluk bilincinin gelişmesine okul ve ailenin etkisi. Eğitim Araştırmaları Dergisi, 10, 175-183.

Yontar, A. (2007). Sorumluluk eğitiminde ceza uygulamalarına ilişkin ilköğretim 5. sınıf öğretmen ve öğrenci görüşlerinin incelenmesi. (Yayınlanmamış yüksek lisans tezi). Çukurova Üniversitesi Sosyal Bilimler Enstitüsü, Adana. 